\title{
TENSILE AND COMPRESSIVE TESTS OF TEXTILE COMPOSITES AND RESULTS ANALYSIS
}

\author{
NATEZNI IN TLAČNI PREIZKUSI TEKSTILNIH KOMPOZITOV IN \\ ANALIZA REZULTATOV
}

\author{
Kryštof Kunc, Tomáš Kroupa, Robert Zemčík, Jan Krystek \\ University of West Bohemia in Plzeň, NTIS, Univerzitní 22, 306 14, Plzeň, Czech Republic \\ ptaeck@kme.zcu.cz \\ Prejem rokopisa - received: 2014-08-01; sprejem za objavo - accepted for publication: 2015-05-05
}

doi:10.17222/mit.2014.167

\begin{abstract}
The presented work is focused on an experimental investigation of the behavior of six types of textile composites subjected to pure tensile, cyclic tensile and compressive loading according to ASTM standards. Each type was loaded in directions forming angles between $0^{\circ}$ and $90^{\circ}$, with a step of $15^{\circ}$ with respect to the reference directions of the weaves. Two types of woven fabrics were tested (plain and quasi-unidirectional plain-woven fabric). Images of specimens taken during the tests were subsequently used for the calculation of the so-called locking angle of yarns (bundles) just before failure. Force-displacement dependencies were recorded during the tensile tests. Ultimate forces were obtained from the compressive tests. The second half of the article is dedicated to the analysis of the experimental data gathered with nearly 1000 experiments. Special software for automatic calculation of averaged dependencies, maximum forces and maximum displacements was created. Furthermore, the methodology for calculating the locking angle was proposed and tested. The obtained results will be used for the identification of the material parameters of the proposed material model in the following research.
\end{abstract}

Keywords: textile composites, woven fabric, tensile test, compressive test, result analysis, weave locking

Prispevek je usmerjen $\mathrm{v}$ eksperimentalno preiskavo obnašanja šestih vrst tekstilnih kompozitov, obremenjenih $\mathrm{z}$ natezno, ciklično-natezno in tlačno obremenitvijo skladno z ASTM standardi. Vsaka vrsta je bila obremenjena v smeri, ki je tvorila kot med $0^{\circ}$ in $90^{\circ}$, s koraki po $15^{\circ}$, glede na smer tkanja. Preizkušeni sta bili dve vrsti tkanin (običajna in kvazi enosmerna običajna tkanina). Posnetki vzorcev med preizkusi so bili uporabljeni za izračun zapornega kota preje (svežnjev) tik pred porušitvijo. Odvisnosti sila-raztezek so bile posnete med nateznimi preizkusi. Končne sile so bile dobljene iz tlačnih preizkusov. Naslednji del prispevka je bil posvečen analizi eksperimentalnih podatkov iz skoraj 1000 preizkusov. Kreirana je bila posebna programska oprema za avtomatsko računanje povprečnih odvisnosti: maksimalnih sil in maksimalnih raztezkov. Poleg tega je bila predlagana in preizkušena metodologija za izračun zapornega kota. Dobljeni rezultati bodo uporabljeni pri nadaljevanju raziskav za določanje parametrov materiala $v$ predlaganem modelu materiala.

Ključne besede: tekstilni kompoziti, tkanina, natezni preizkus, tlačni preizkus, analiza rezultatov, zaklepanje vezave

\section{INTRODUCTION}

Textile composites made from carbon, glass and aramid fibers are nowadays commonly used. However, to be able to simulate the behavior of these modern materials as in the case of classical metals, it is appropriate to use complex mathematical models with many more material parameters. A significantly non-linear behavior of composite materials is caused by different properties of its components and by a complicated manufacturing process. Sophisticatedly gathered data from many experimental tests are, therefore, required for identifying material parameters and designing modern tailored composite structures. ${ }^{1}$

\section{EXPERIMENTAL PART}

Experimental tests were focused on three composite types - glass, carbon and aramid. Each type was tested in two woven-fabric versions: a) a plain weave with a $1: 1$ fiber ratio and b) a quasi-unidirectional plain weave with a 1:9 fiber ratio. ${ }^{2}$
The following markings are used to describe all the tested specimens: GP - glass plain weave, GU - glass quasi-unidirectional weave, $\mathrm{CP}$ - carbon plain weave, $\mathrm{CU}$ - carbon quasi-unidirectional weave, AP - aramid plain weave and AU - aramid quasi-unidirectional weave.

The tested specimens (coupons) were cut from six composite plates, manufactured with the RTM technology, using a water jet to get seven different groups of specimens with the principal material orientation $\theta$ of the weave (between $0^{\circ}$ and $90^{\circ}$ with a step of $15^{\circ}$ ) with respect to each coupon's longitudinal axis (and load direction). Average thicknesses of the coupons are shown in Table 1.

Table 1: Average thicknesses of composite plates

Tabela 1: Povprečne debeline kompozitnih plošč

\begin{tabular}{|c|c|c|c|}
\hline Material & $t(\mathrm{~mm})$ & Material & $t(\mathrm{~mm})$ \\
\hline GP & 1.8 & GU & 1.8 \\
\hline CP & 2.0 & CU & 1.5 \\
\hline AP & 2.2 & AU & 2.0 \\
\hline
\end{tabular}




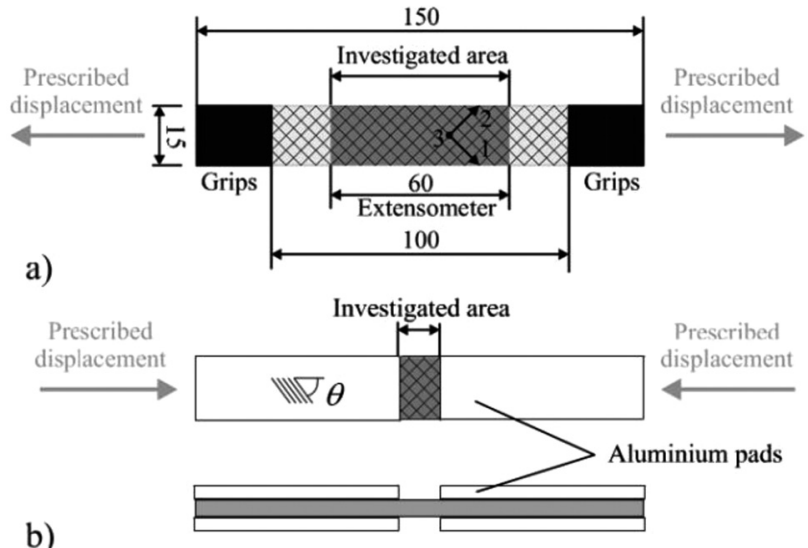

Figure 1: Dimensions of specimens for: a) tensile and b) compressive tests and the principal material orientation

Slika 1: Dimenzije vzorcev za: a) natezne in b) tlačne preizkuse in glavna orientacija materiala

To ensure the objectivity of the measurement, a minimum of seven specimens for each material, weave type and weave orientation was prepared.

Three types of tests were performed on a Zwick/ Roell Z050 machine - pure tensile, cyclic tensile and compressive loading - according to ASTM standards. ${ }^{3}$ For the following experiment analysis, data from a minimum of six identical tests were accepted. The total number of specimens for one experiment (tensile/cyclic tensile/compressive) is seven coupons for seven material orientations multiplied by three different materials and two types of woven fabrics. In total, nearly 1000 specimens were tested, including the preliminary work.

Typical specimen set-ups before the tensile a) and compressive b) tests and their dimensions are shown in Figure 1. Cyclic tensile tests were driven by the prescribed displacement with amplitude $\Delta l=1 \mathrm{~mm}$. In the finished cyclic tests, the number of hysteresis loops for the same specimens was not always the same. This is evident from the result graphs, where the tangents of a few last load/unload cycles are missing.
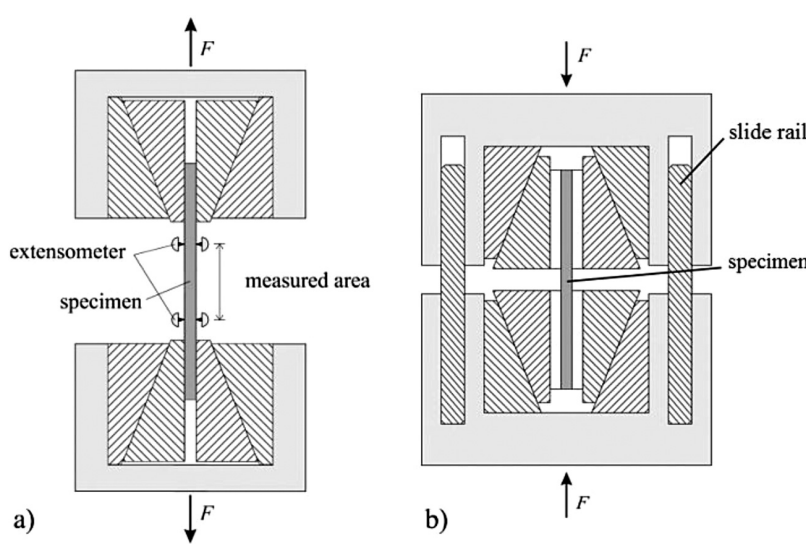

Figure 2: a) Tensile- and b) compressive-test schemes Slika 2: Shemi: a) nateznega preizkusa in b) tlačnega preizkusa

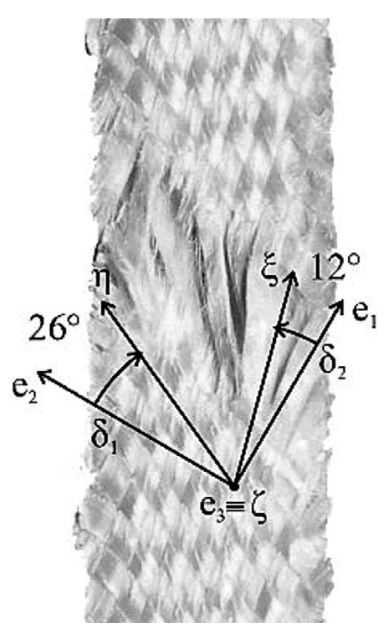

Figure 3: Aramid plain-weave specimen $\left(\theta=30^{\circ}\right)$ and locking-angle interpretation

Slika 3: Vzorec aramida $\mathrm{z}$ navadnim valom $\left(\theta=30^{\circ}\right)$ in predstavitev zapornega kota

The tensile tests for the plain-woven fabrics were less problematic than the ones for the quasi-unidirectional plain-woven fabrics, which had to be equipped with aluminium pads in numerous cases to avoid a premature destruction of a coupon by machine grips and to get acceptable results from the experiment. All the coupons for the compressive tests had to be prepared with aluminium pads to achieve the proper attachment to the testing machine. ${ }^{4}$ The schemes shown in Figure 2 represent typical experimental set-ups for the tensile (a) and compressive tests (b).

All the specimens subjected to the tensile tests (loading) were photographed to identify the so-called locking angle. ${ }^{5}$

The locking angle (Figure 3 ) is defined by two angles, $\delta_{1}$ and $\delta_{2}$, representing the diversions of the principal material directions, just before the rupture (axes $\xi, \eta, \xi$ ), from their initial states (axes $e_{1}, e_{2}, e_{3}$ ). This phenomenon was most notable on the specimens made of the aramid textile and least notable on the glass textile. Similarly, for the boundary material orientations
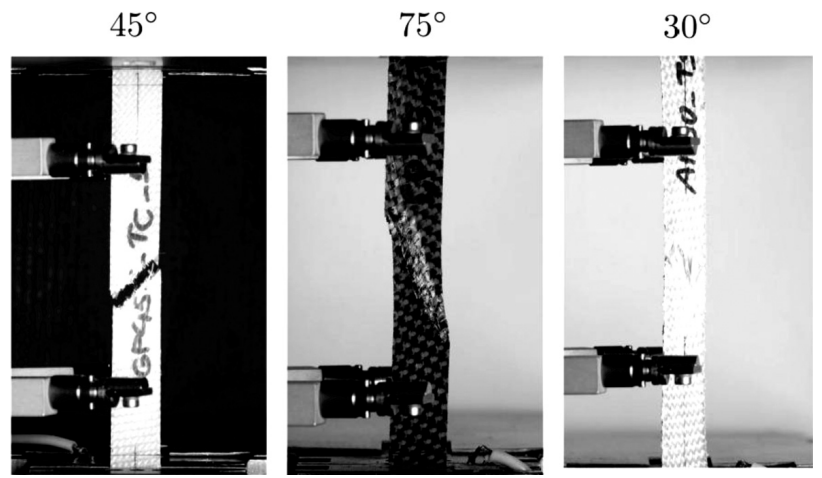

Figure 4: Photographs of selected plain-weave specimens after the tensile test (GP, CP, AP)

Slika 4: Posnetki izbranih vzorcev z navadnim valom po nateznem preizkusu (GP, CP, AP) 

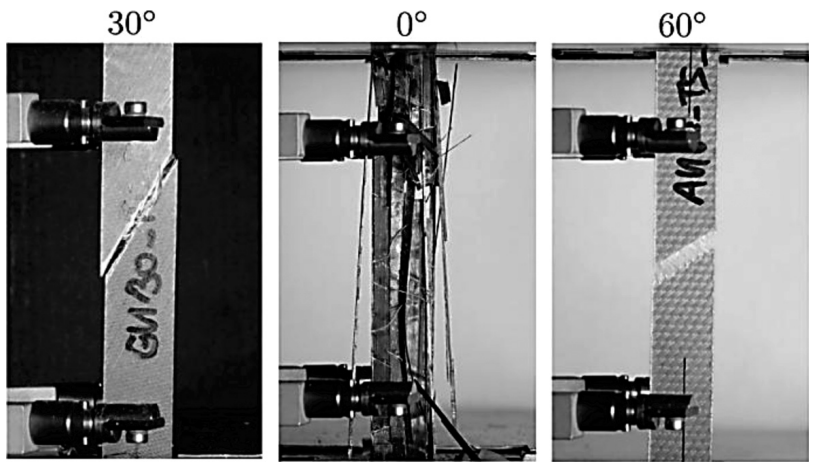

Figure 5: Photographs of selected quasi-unidirectional plain-weave specimens after the tensile test (GU, CU, AU)

Slika 5: Posnetki izbranih vzorcev s kvazi-enosmerno, običajno vezavo po nateznem preizkusu

of $\theta=0^{\circ}$ and $\theta=90^{\circ}$ and quasi-unidirectional plainweave composites made of carbon and glass, no significant weave-locking phenomenon was proven. Carbon composites with plain weave showed a high strength during the tests and never ruptured completely (excluding the boundary orientations). Photographs of selected specimens taken after the tensile test are shown on Figure 4 (with plane weave) and Figure 5 (with quasi-unidirectional plain weave).

A further description of implementing the measured data into the identification process and the details of the material model can be found in another paper of the above co-authors. ${ }^{6}$

\section{ANALYSIS OF THE EXPERIMENTAL DATA}

Standalone application ploTra was written in the Python programming language for the processing of a large amount of experimental data. The application is designed to read experimental data from the Zwick/Roell

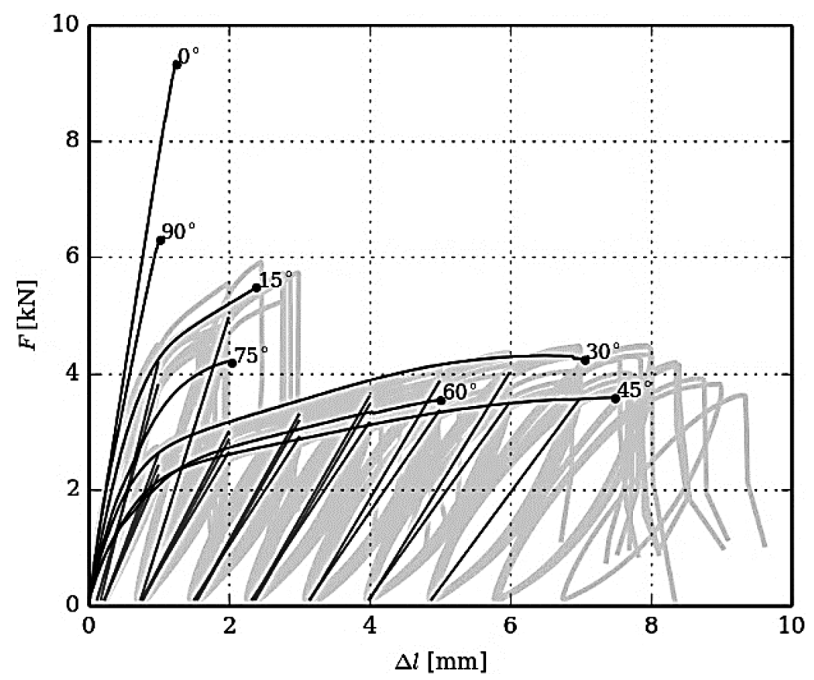

Figure 6: Averaged force-displacement dependencies and tangent of unload/load cycle for GP composite

Slika 6: Povprečna odvisnost sila-raztezek in tangenta na neobremenjen/obremenjen cikel pri GP kompozitu

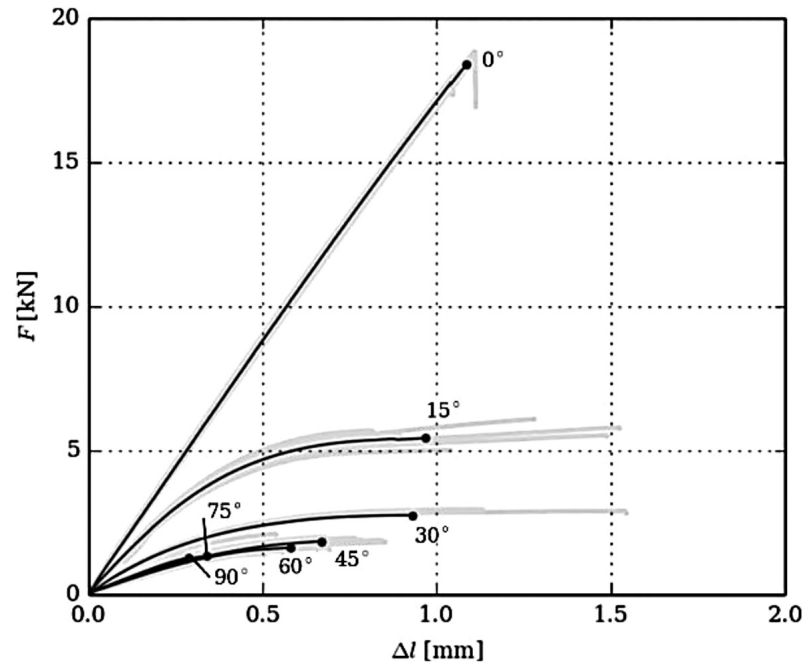

Figure 7: Averaged force-displacement dependencies for GU composite

Slika 7: Povprečna odvisnost sila-raztezek pri GU kompozitu

software (in the TRA format) and execute multiple operations resulting in the following outputs:

Averaged force-displacement dependencies (dark curves in the presented graphs). The application accepts data from one sorted set of measurements and calculates the average using one of the various available methods, e.g., 2D averaging, averaging in a given interval, or the arc length. The results are saved as graphs (PNG/PDF) and binary files for future usage.

Averaged tangents (slopes) of unload/load cycles (straight lines in the presented graphs). All the hysteresis loops from the cyclic tensile tests are identified; their lowest and highest points are connected to form lines, the tangents of which are averaged for each experiment group including the specimens with the same orientation. It was observed that these tangents were not constant during the tests.

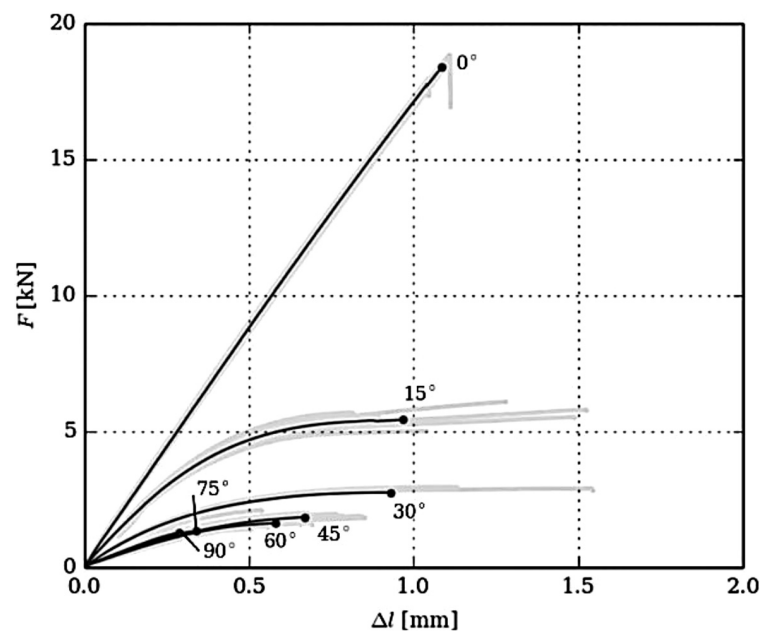

Figure 8: Averaged force-displacement dependencies and tangent of unload/load cycle for CP composite

Slika 8: Povprečje odvisnosti sila-raztezek in tangenta cikla neobremenjeno/obremenjeno pri CP kompozitu 


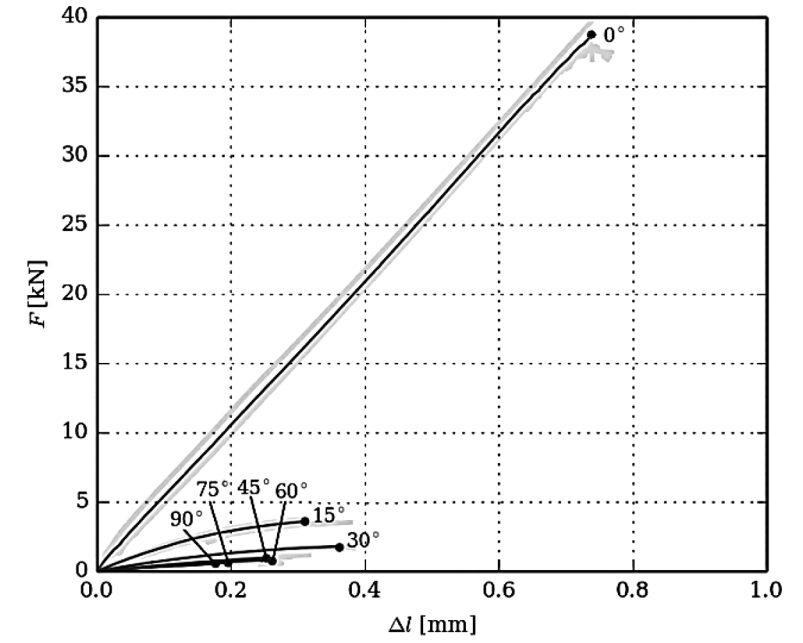

Figure 9: Averaged force-displacement dependencies for CU composite

Slika 9: Povprečje odvisnosti sila-raztezek pri CU kompozitu

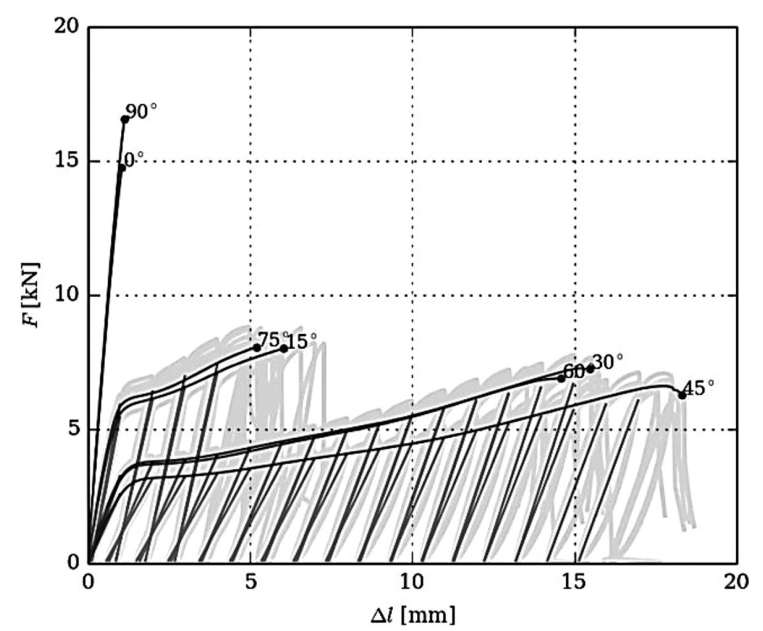

Figure 10: Averaged force-displacement dependencies and tangent of unload/load cycle for AP composite

Slika 10: Povprečje odvisnosti sila-raztezek in tangenta cikla razbremenjeno/obremenjeno pri AP kompozitu

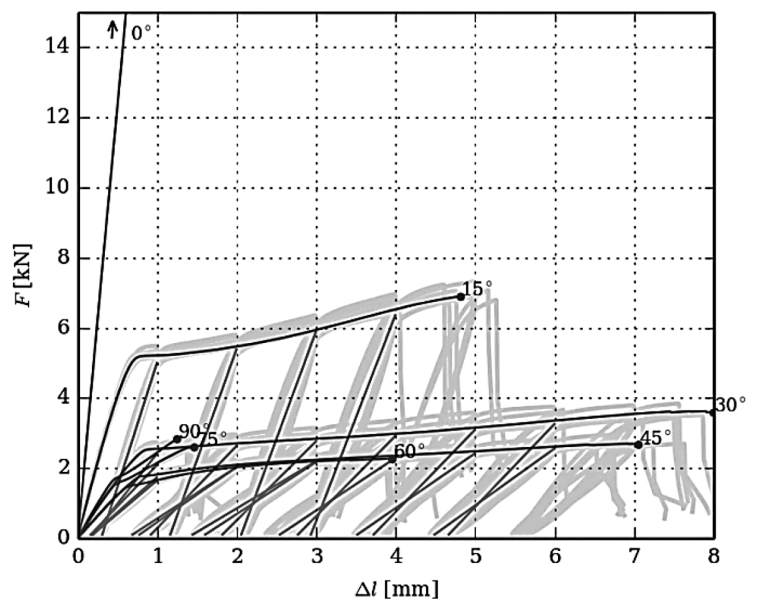

Figure 11: Averaged force-displacement dependencies and tangent of unload/load cycle for AU composite

Slika 11: Povprečje odvisnosti sila-raztezek in tangenta cikla neobremenjeno/obremenjeno pri AU kompozitu
Tables with averaged statistical data - the maximum forces and displacements including standard deviations.

\section{RESULTS}

The tables and graphs below represent the outputs from the ploTra application. The maximum tensile and ultimate forces of the compressive tests are shown in Tables 2 and 3. Averaged force-displacement dependencies (Figures 6 to 11) are suitable for the use of the complex material model including damage. The weavelocking angles shown in Tables $\mathbf{4}$ and $\mathbf{5}$ were collected using the common tools available in graphics editors.

Table 2: Tensile tests - average maximum forces in $(\mathrm{kN})$

Tabela 2: Natezni preizkusi - povprečje maksimalnih sil $(\mathrm{kN})$

\begin{tabular}{|c|c|c|c|c|c|c|}
\hline$\theta$ & GP & GU & CP & CU & AP & AU \\
\hline $0^{\circ}$ & 9.50 & 18.45 & 20.20 & 39.71 & 16.01 & 29.50 \\
\hline $15^{\circ}$ & 5.68 & 5.63 & 9.33 & 3.66 & 8.25 & 7.03 \\
\hline $30^{\circ}$ & 4.33 & 2.78 & 5.96 & 1.80 & 7.33 & 3.66 \\
\hline $45^{\circ}$ & 3.63 & 1.91 & 5.28 & 0.99 & 6.63 & 2.73 \\
\hline $60^{\circ}$ & 3.66 & 1.67 & 5.77 & 0.82 & 7.01 & 2.30 \\
\hline $75^{\circ}$ & 4.23 & 1.39 & 9.18 & 0.60 & 8.37 & 2.67 \\
\hline $90^{\circ}$ & 6.40 & 1.36 & 19.09 & 0.57 & 17.37 & 2.87 \\
\hline
\end{tabular}

Table 3: Compressive tests - average ultimate forces $(\mathrm{kN})$

Tabela 3: Tlačni preizkusi - povprečje končnih sil $(\mathrm{kN})$

\begin{tabular}{|c|c|c|c|c|c|c|}
\hline$\theta$ & GP & GU & CP & CU & AP & AU \\
\hline $0^{\circ}$ & 8.32 & 13.21 & 12.01 & 11.70 & 4.89 & 5.36 \\
\hline $15^{\circ}$ & 6.71 & 4.71 & 7.32 & 5.74 & 4.69 & 5.37 \\
\hline $30^{\circ}$ & 4.03 & 4.25 & 4.91 & 3.75 & 3.77 & 3.99 \\
\hline $45^{\circ}$ & 3.67 & 4.01 & 4.51 & 3.16 & 3.70 & 3.46 \\
\hline $60^{\circ}$ & 3.96 & 3.96 & 4.75 & 2.81 & 4.01 & 3.37 \\
\hline $75^{\circ}$ & 4.85 & 4.04 & 7.13 & 2.55 & 4.68 & 3.45 \\
\hline $90^{\circ}$ & 4.20 & 4.05 & 11.6 & 2.54 & 4.70 & 3.52 \\
\hline
\end{tabular}

Table 4: Averaged weave-locking angles $\delta_{1}$ and $\delta_{2}$ for plain-weave composites in $\left(^{\circ}\right)$

Tabela 4: Povprečje kota tkanja $\delta_{1}$ in $\delta_{2}$ za običajno tkane kompozite $\mathrm{v}\left({ }^{\circ}\right)$

\begin{tabular}{|c|c|c|c|c|c|c|}
\hline$\theta$ & \multicolumn{2}{|c|}{$\mathrm{GP}$} & \multicolumn{2}{c|}{$\mathrm{CP}$} & \multicolumn{2}{c|}{$\mathrm{AP}$} \\
\hline $0^{\circ}$ & 0.00 & 0.00 & 0.00 & 0.00 & 0.00 & 0.00 \\
\hline $15^{\circ}$ & 2.30 & 2.00 & 8.60 & 1.30 & 17.80 & 2.60 \\
\hline $30^{\circ}$ & 5.00 & 3.50 & 12.80 & 5.80 & 26.70 & 12.30 \\
\hline $45^{\circ}$ & 7.50 & 7.10 & 13.30 & 12.50 & 17.30 & 18.00 \\
\hline $60^{\circ}$ & 3.10 & 3.30 & 8.50 & 20.60 & 9.80 & 22.50 \\
\hline $75^{\circ}$ & 1.10 & 3.20 & 1.50 & 11.70 & 1.30 & 17.00 \\
\hline $90^{\circ}$ & 0.00 & 0.00 & 0.00 & 0.00 & 0.00 & 0.00 \\
\hline
\end{tabular}

\section{CONCLUSION}

All the materials showed a complex non-linear behavior.

- Force-displacement dependencies are non-linear even for the plain-weave material orientations of $\theta=0^{\circ}$ and $\theta=90^{\circ}$. Hardening was noticed in the case of carbon and aramid textiles (exhibiting a convex 
load-displacement curve when zoomed) and softening (a concave curve) was noticed in the case of glass textile.

- Specimens made of aramid fibers reached the highest strength during the tests; on the other hand, glassfiber specimens reached the lowest strength.

- Weave-locking phenomenon has significant impacts on the plain-weave orientations of $\theta=45^{\circ}$ - plastic behavior of the tested materials was observed.

- Unsymmetrical results for the plain-weave composites are probably caused by an imperfect technology of manufacturing the textiles or by the preparation of the specimens.

\section{Acknowledgements}

This publication was supported by the project L01506 of the Czech Ministry of Education, Youth and Sports and by the project of University of West Bohemia SGS-2016-038.

\section{REFERENCES}

${ }^{1}$ R. Böhm, W. Hufenbach, Experimentally based strategy for damage analysis of textile-reinforced composites under static loading, Composites Science and Technology, 70 (2010) 9, 1330-1337, doi:10.1016/j.compscitech.2010.04.008

${ }^{2}$ T. Kroupa, P. Janda, R. Zemčík, Linear two scale model for determination of mechanical properties of textile composite material, Mater. Tehnol., 46 (2012) 2, 97-101

${ }^{3}$ ASTM Standard D 3039 / D 3039M - 08, 2008, Standard Test Method for Tensile Properties of Polymer Matrix Composite Materials, ASTM International, West Conshohocken, PA 19428-2959, 2003, www.astm.org

${ }^{4}$ ASTM Standard D 3410 / D 3410M - 03, 2008, Standard Test Method for Compressive Properties of Polymer Matrix Composite Materials, ASTM International, West Conshohocken, PA 19428-2959, 2003, www.astm.org

${ }^{5}$ N. Hamila, P. Boisse, Locking in simulation of composite reinforcement deformations, Analysis and treatment, Composites Part A, Applied Science and Manufacturing, 53 (2013), 109-117 doi:10.1016/j.compositesa.2013.06.001

${ }^{6}$ T. Kroupa, K. Kunc, R. Zemčik, T. Mandys, Non-linear finite elements simulations of the tensile tests of textile composites, Mater. tehnol., 49 (2015) 4, 509-515, doi:10.17222/mit.2014.117 